\title{
Effects of Triploidy on Hematological Characteristics and Oxygen Consumption in Ayu
}

\author{
Ratu Siti Aliah, ${ }^{* 1}$ Yoshikazu Inada, ${ }^{* 2}$ Kosaku Yamaoka, ${ }^{* 1}$ \\ and Nobuhiko Taniguchi ${ }^{* 1}$ \\ (Received October 15, 1990)
}

\begin{abstract}
The hematological characteristics and oxygen consumption of diploid and triploid ayu Plecoglossus altivelis were examined to understand the physiological difference between them. Triploids were larger in erythrocyte size but smaller in erythrocyte number than diploids. The nuclei in triploids were also larger than in diploids. Values of $\mathrm{MCV}$ and $\mathrm{MCH}$ in triploids were larger than in diploids. The values of hematocrit, hemoglobin and MCHC were almost the same in both ploidies. Triploids tended to show higher oxygen consumption than diploids, but the difference was not statistically significant.
\end{abstract}

Erythrocytes and their nuclei are larger in triploid fish than those in diploid one. ${ }^{1-6)}$ How. ever, the increase in erythrocyte volume of triploids is compensated by a reduction in erythrocyte number, causing the hematocrit value and total hemoglobin content being the same in diploids and triploids. ${ }^{7)}$ The difference of the erythrocyte size between diploids and triploids is also used for a rapid method to identify the ploidy ${ }^{5,8,0)}$ As an oxygen transport agent, the erythrocyte plays an important role in bringing oxygen from the external medium to the cell, so that the alteration of the hematological characteristics might influence the ability of fishes to utilize oxygen in reared conditions. The present study is intended as a contribution towards our understanding of the difference in hematology and oxygen consumption between tripoid and diploid ayu Plecoglossus altivelis.

\section{Materials and Methods}

Triploid and diploid ayu $P$. altivelis used in this study were obtained from the Fukuoka Prefectural Fisheries Experimental Station. Triploidy was produced by the cold shock treatment following the methods of Taniguchi et al. ${ }^{10}$ ) The experiments were conducted from August to October, 1987.

A blood sample was withdrawn from the caudal vein using a $1 \mathrm{~m} l$ disposal plastic syringe fitted with a 23 gauge-needle. The hemoglobin content of $0.02 \mathrm{~m} l$ of blood was quantified by the cyanmethemoglobin method. The heparinized capillary hematocrit tube was used to determine the hematocrit value of each fish. After filling the tube with blood, the blood was centrifuged at $8000 \mathrm{rpm}$ for $5 \mathrm{~min}$ and the volume of packed red blood cells was read by a hematocrit reader. Blood smears were prepared from each fish by the conventional method, fixed in methylalcohol, stained for $30 \mathrm{~min}$ with Giemsa, rinsed with tap water and air-dried.

The length and width of cells and nuclei were measured with 20 erythrocytes from each fish. Areas of the longitudinal section of cells and nuclei were computed for each fish by an equation, area of the longitudinal section: $S=\pi a b$, where $a$ and $b$ were the radius of major and minor axes, respectively of a cell and a nucleus. A RBC Unopette microcollection system (Becton, Dickinson and Company, Cat. No. 5851) was used to count the number of erythrocyte and Thomahemocytometer to count the cells in the RBC Unopette dilution. The Mean Corpuscular Volume (MCV), the Mean Corpuscular Hemoglobin (MCH) and the Mean Corpuscular Hemoglobin Concentration (MCHC) were calculated using the formulae according to Clark et al. ${ }^{11}$

The oxygen consumption was measured by placing the individual fish in a respiration chamber, $26 \mathrm{~cm}$ in length and $4 \mathrm{~cm}$ in diameter, made of cylindrical transparent plastic. The chamber

*1 Department of Cultural Fisheries, Faculty of Agriculture, Kochi University, Nankoku, Kochi 783, Japan (R.S. Aliah, 山周耕作，谷口順彦：商知大学蛿学部栽培源業学科).

*2 Fukuoka Prefectural Freshwater Fisheries Experimental Station, Asakura, Fukuoka 838-13, Japan (移田菩和：福岡紧内水面水産試験場). 
was placed in a $80 l$ water tank, of which water was kept overflowing. The water flew at a rate of $12.18-24.40 \mathrm{l} / \mathrm{hr}$ (constant flow method). Water temperature was almost constant between 18.7$19.4^{\circ} \mathrm{C}$ and oxygen concentration of the water was over $85 \%$ saturation. The inflow water was branched, one proceeding to the respiration chamber and the other to the $1 l$ beaker which was stirred during the observation. The same treatment was also made at the outflow water. Then the inflow and outflow water was collected by BOD bottle and the dissolved oxygen was analyzed by the Winkler method. ${ }^{12}$ The oxygen consumption of diploid and triploid ayu was calculated according to Itazawa. ${ }^{132}$

The data were statistically analyzed by Student's $t$-test.

\section{Results}

\section{Hematological Characteristics}

The hematological characteristics of diploid and triploid ayu are summarized in Table 1. No clear difference was found in the values of the six characteristics between male and female in both ploidies. In the values of erythrocyte count, $\mathrm{MCV}$ and $\mathrm{MCH}$, clear differences were detected between two ploidies. Triploids showed $65.25 \%$ and $76.08 \%$ increase in the $\mathrm{MCV}$ and $\mathrm{MCH}$, respectively, and a $41.82 \%$ decrease in the erythrocyte count compared to those in diploids, with the result that the values of hematocrit, hemoglobin and MCHC were almost the same in both ploidies.

An increase in triploid's $\mathrm{MCV}$ was mainly due to an increase of the major axis of erythrocyte, although there was also an increase in its minor axis (Fig. 1, Table 2). In triploids, the mean of major axis dimension of erythrocytes was 1.32 times larger than diploids. The same tendency was also found in erythrocyte nuclei (Table 2). The ratios of the area of the longitudinal section of the nuclei to that of the cells of both ploidies were almost the same, 0.15 in diploids and 0.16 in triploids.

\section{Oxygen Consumption}

The result of oxygen consumption experiment of 7 diploids and 12 triploids is shown in Table 3.

Table 1. Hematological characteristics of triploid and diploid ayu (Mean \pm S.D.)

\begin{tabular}{|c|c|c|c|c|}
\hline & \multicolumn{2}{|c|}{ Triploid } & \multicolumn{2}{|c|}{ Diploid } \\
\hline & Female & Male & Female & Male \\
\hline No. of fish & 5 & 5 & 5 & 5 \\
\hline Body weight (g) & $65.28 \pm 17.90$ & $59.92 \pm 12.99$ & $73.75 \pm 5.55$ & $51.25 \pm 5.53$ \\
\hline Fork length $(\mathrm{cm})$ & $17.00 \pm 2.47$ & $16.78 \pm 1.39$ & $16.89 \pm 0.44$ & $16.15 \pm 1.00$ \\
\hline $\begin{array}{l}\text { Erythrocyte number } \\
\left(\mathrm{million} / \mathrm{mm}^{3}\right)\end{array}$ & $2.26 \pm 0.14$ & $2.22 \pm 0.24$ & $3.75 \pm 0.33$ & $3.95 \pm 0.18$ \\
\hline Hemoglobin $(\mathrm{g} / 100 \mathrm{~m} l)$ & $10.07 \pm 0.65$ & $9.76 \pm 1.28$ & $9.46 \pm 0.74$ & $10.24 \pm 0.60$ \\
\hline Hematocrit $(\%)$ & $38.40 \pm 3.99$ & $37.66 \pm 4.37$ & $39.82 \pm 5.21$ & $39.95 \pm 3.86$ \\
\hline $\operatorname{MCV}\left(\mu \mathrm{m}^{3}\right)$ & $170.07 \pm 16.15$ & $169.99 \pm 8.38$ & $104.75 \pm 4.98$ & $101.03 \pm 7.00$ \\
\hline $\mathrm{MCH}(\mu \mu \mathrm{g})$ & $44.73 \pm 4.44$ & $45.53 \pm 2.62$ & $25.33 \pm 1.58$ & $25.93 \pm 1.20$ \\
\hline MCHC (\%) & $26.34 \pm 1.93$ & $26.78 \pm 0.72$ & $23.92 \pm 1.79$ & $25.74 \pm 1.86$ \\
\hline
\end{tabular}

Table 2. Erythrocyte dimensions of triploid and diploid ayu

\begin{tabular}{lccc}
\hline & Triploid & Diploid & $\begin{array}{c}\text { Ratio of Triploid } \\
\text { to Diploid }\end{array}$ \\
\hline No. of fish & 15 & 15 & \\
Erythrocyte: & & & $1.32^{* 1}$ \\
$\quad$ Major axis $(\mu \mathrm{m})$ & $11.90 \pm 0.40$ & $9.03 \pm 0.35$ & $1.07^{* 1}$ \\
$\quad$ Minor axis $(\mu \mathrm{m})$ & $6.58 \pm 0.31$ & $6.13 \pm 0.30$ & $1.42^{* 1}$ \\
$\quad$ Area of longitudinal & $61.61 \pm 3.88$ & $43.43 \pm 3.17$ & \\
$\quad$ section $\left(\mu \mathrm{m}^{2}\right)$ & & & $1.41^{* 1}$ \\
Nucleus of erythrocyte & $5.31 \pm 0.19$ & $3.76 \pm 0.19$ & $1.05^{* 2}$ \\
$\quad$ Major axis $(\mu \mathrm{m})$ & $2.31 \pm 0.13$ & $2.19 \pm \mathbf{0 . 1 3}$ & $1.49^{* 1}$ \\
$\quad$ Minor axis $(\mu \mathrm{m})$ & $9.61 \pm 0.76$ & $6.46 \pm 0.67$ & \\
$\quad$ Area of longitudinal & section $\left(\mu \mathrm{m}^{2}\right)$ & &
\end{tabular}




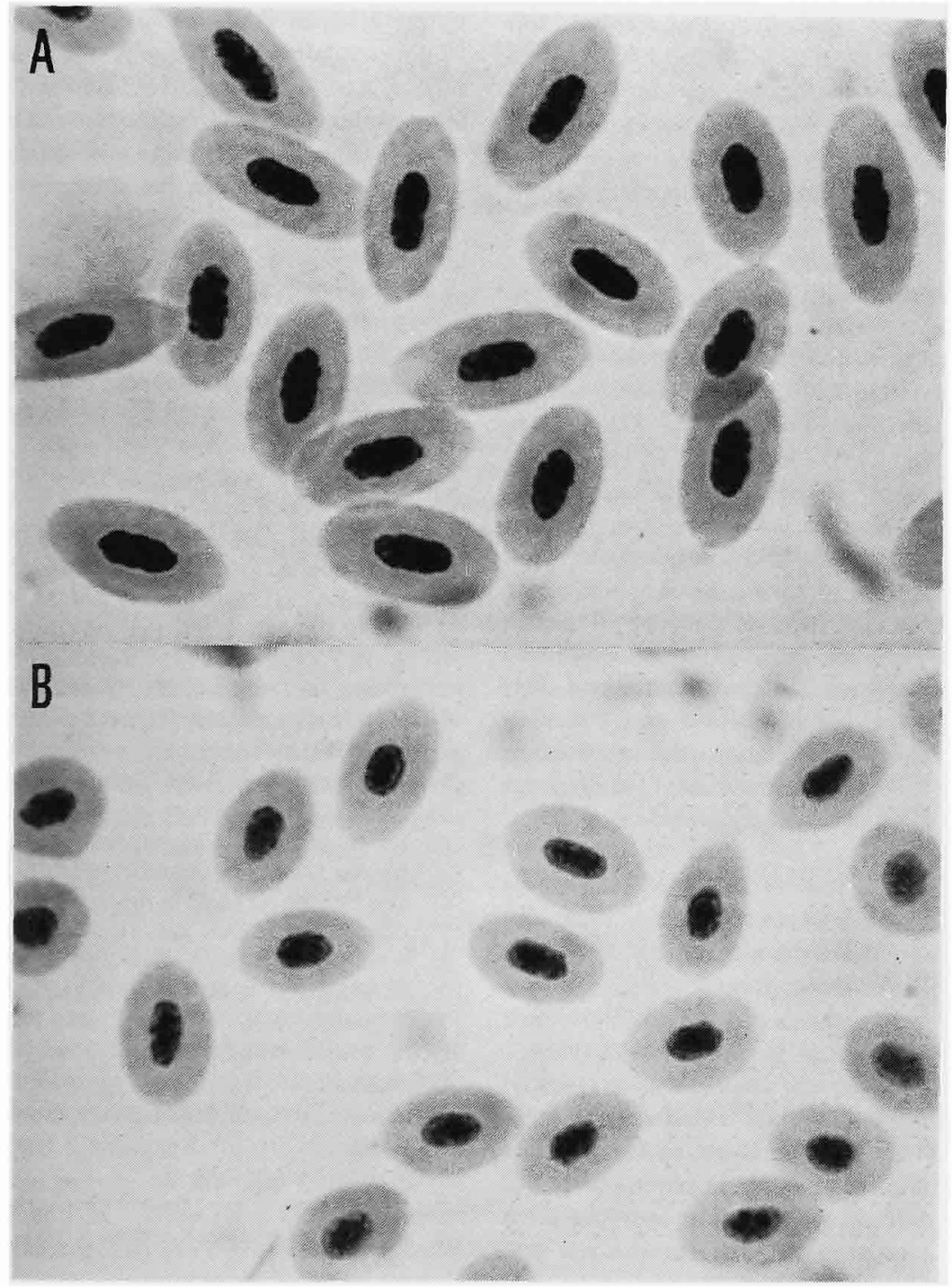

Fig. 1. Erythrocytes in triploid (A) and diploid (B) ayu. $\times 500$.

Table 3. Respiration of triploid and diploid ayu. Note that the sample size for ventilation rate is different from that for others as shown in parentheses (Mean $\pm \mathrm{SD}$ )

\begin{tabular}{lcc}
\hline & Triploid & Diploid \\
\hline No. of fish & 12 & 7 \\
Body weight $(\mathrm{g})$ & $43.18 \pm 7.80$ & $53.00 \pm 8.42$ \\
Fork length $(\mathrm{cm})$ & $15.31 \pm 0.90$ & $15.70 \pm 1.00$ \\
Water flow through respiration chamber $(l / \mathrm{h})$ & $21.00 \pm 3.59$ & $22.24 \pm 2.08$ \\
Ventilation rate $(/ 10 \mathrm{sec})$ & $25.91 \pm 3.09(11)^{*}$ & $23.40 \pm 2.42(5)$ \\
Oxygen consumption $(\mathrm{m} l / \mathrm{kg}, \mathrm{hr})$ & $363.36 \pm 68.51^{*}$ & $325.99 \pm 55.51$ \\
\hline
\end{tabular}

* Not significant at $P>0.05$. 
The mean oxygen consumption of triploids was $363.36 \mathrm{~m} / \mathrm{kg}$, $\mathrm{hr}$, ranging from 265.77 to 494.20 $\mathrm{m} / \mathrm{kg}$, hr; higher than that of diploids, which was 325.99 , ranging from 208.76 to $390.12 \mathrm{~m} / \mathrm{kg}$, hr. However, the difference was not significant. The ventilation rate in both ploidies also did not show any significant difference (Table 3 ).

\section{Discussion}

The presence of a third set of chromosome in triploids generally causes an increase in size of individual cells. However, triploid animals are not larger than diploid ones due to the inverse relation in number of cells. ${ }^{1,14)}$ The homeostatic mechanism of the erythrocytes has been found in sticklebacks, ${ }^{1)}$ goldfish, ${ }^{3)}$ channel catfish $^{4)}$ and grass carp $X$ bighead carp hybrids, ${ }^{5)}$ which are larger in size in triploids than diploids. The present results in hematology of triploid ayu are consistent with these findings. Benfey and Sutterlin $^{(1)}$ suggested that a decrease in erythrocyte number in triploids was due to the homeostatic mechanism to maintain the similar hemoglobin concentration to that of diploids in the blood plasma.

Area of the longitudinal section of each erythrocyte of triploid ayu is larger than that of diploid one. However, the total area, available for the oxygen uptake, of the erythrocytes included in a given quantities of the blood is less in triploids $\left(138.00 \mathrm{~mm}^{2} / \mathrm{mm}^{3}\right)$ than in diploids $\left(167.21 \mathrm{~mm}^{2}\right)$ $\mathrm{mm}^{3}$ ). On the contrary, hemoglobin contents in the blood of triploids and diploids are very similar each other (Table 1). In normoxic condition of $85 \%$ air saturation or more, triploid ayu is not statistically different from diploid one in relation to oxygen consumption. The same result was given in the stickleback ${ }^{15}$ and landlocked Atlantic salmon. ${ }^{10)}$ However, at a low level of oxygen concentration, the respiratory activity of triploid ayu was weakened more severely than diploid one.* Therefore, the efficiency of oxygen uptake by erythrocytes might be lower in triploids than in diploids probably owing to the smaller total surface area of erythrocytes, despite the hemog. lobin content being almost the same as in diploids. In fact, triploid ayu is more susceptible to a low oxygen concentration in the environmental water that diploid one in our breeding stock.

\section{Acknowledgments}

We thank Mr. Hiroyuki Hatanaka, Kochi University, for his kind support during the course of this study.

\section{References}

1) H. Swarup: J. Genet., 56, 143-155 (1959).

2) R. J. Valenti: J. Fish Biol., 7, 519-528 (1975).

3) K. Sezaki, H. Kobayashi, and M. Nakamura: Japan. J. Ichthyol, 24, 135-140 (1977).

4) W. R. Wolters, C. L. Chrisman, and G.S. Libey: J. Fish Biol., 20, 253-258 (1982).

5) M. L. Beck and C. J. Biggers: J. Fish Biol., 22 , 497-502 (1983).

6) T.J. Benfey and A. M. Sutterlin: J. Fish Biol., 24, 333-338 (1984).

7) K. Sezaki, S. Watabe, and K. Hashimoto: Nippon Suisan Gakkaishi, 49, 97-101 (1983).

8) T. J. Benfey, A. M. Sutterlin, and R. J. Thompson: Can. J. Fish. Aquat. Sci., 41, 980-984 (1984).

9) K. Ueno: Japan. J. Genet., 59, 585-591 (1984).

10) N. Taniguchi, A. Kijima, J. Fukai, and Y. Inada: Nippon Suisan Gakkaishi, 52, 49-53 (1986).

11) S. Clark, D. H. Whitemore Jr., and R. F. McMahon: J. Fish Biol., 14, 147-158 (1979).

12) T. Mizuno: in "Seitaigaku Jisshyusho" (ed. by Seitaigaku Jisshyu Kondankai), Asakurashoten, Tokyo, 1967, pp. 39-49.

13) Y. Itazawa: in "Gyorui Seirigaku Gairon" (ed. by T. Tamura), Koseisha Koseikaku, Tokyo, 1977, pp. 1-33.

14) G. Fankhauser: J. Exp. Zool, 100, 445-455 (1945).

15) H. Swarup: J. Genet., 56, 156-160 (1959).

16) T. J. Benfey and A. M. Sutterlin: Aquaculture, 42, 69-73 (1984).

* N. Taniguchi, J. Fukai, and Y. Inada: Summary of lecture No. 446 in spring meeting of Nippon Suisan Gakkai in 1986.

Nippon Suisan Gakkaishi : Formerly Bull. Japan. Soc. Sci. Fish. 